$\begin{array}{r}\text { Volume and Issues Obtainable at Center for Sustainability Research and Consultancy } \\ \text { Journal of Business and Social Review in Emerging Economies } \\ \text { ISSN: 2519-089X (E): 2519-0326 } \\ \text { Volume 6: No. 4, December } 2020 \\ \text { JSRC } \\ \text { Journal homepage: www.publishing.globalcsrc.org/jbsee } \\ \hline\end{array}$

\title{
Media Framing of Pandemics: A Case Study of the Coverage of COVID-19 in Elite Newspapers of Pakistan
}

\author{
${ }^{1}$ Ayesha Siddiqua, ${ }^{2}$ Ghulam Shabir, ${ }^{3}$ Atif Ashraf, ${ }^{4}$ Ammad Khaliq \\ ${ }^{1}$ Lecturer, Department of Mass Communication, National University of Modern Languages, Islamabad, \\ Pakistan, ayeshasiddiqua05@gmail.com \\ ${ }^{2}$ Professor, Faculty of Media and Communication Studies, University of Central Punjab, Lahore, \\ Pakistan, \\ drshabair@yahoo.com ghulam.shabir@ucp.edu.pk \\ ${ }^{3}$ Assistant Professor, Faculty of Media and Communication Studies, University of Central Punjab, \\ Lahore, Pakistan, \\ atifashraf@ucp.edu.pk \\ ${ }^{4}$ Multimedia and Broadcast Journalist, BBC

\begin{tabular}{l}
\hline ARTICLE DETAILS \\
\hline History \\
Revised format: November \\
2020 \\
Available Online: December \\
2020 \\
\hline Keywords \\
Pandemic; Media Framing; \\
Coronavirus (COVID-19); $e$ \\
papers
\end{tabular} \\ JEL Classification \\ MO, $M 1$ \\ ABSTRACT \\ Considering the outbreak of Corona pandemic as a case study the \\ article explores the dominant frames used in the coverage of COVID- \\ 19 pandemic by the Pakistani English e papers. The media framing is \\ analyzed through qualitative inductive content analysis of the \\ COVID-19 related news stories published in the e papers of Dawn \\ and Express Tribune. Three broad themes emerged as a result of the \\ inductive content analysis which included Scientific Development \\ related to Pandemic; Scale of Pandemic; Social and Economic Impact \\ of Pandemic. The results indicated that the coverage by the e papers \\ was mostly aimed at educating the readers; difficult jargon related to \\ medicine was mostly avoided and where the use of jargon was \\ unavoidable it was properly explained. Most of the stories were \\ developing in nature as the pandemic itself was unfolding at a very \\ fast pace during the selected time frame. The news related \\ information was mostly compiled in a manner which was meant to \\ both warn the readers and the policy makers about the growing scale \\ of the pandemic. The coverage also provided recommendations for \\ the revival of economic and social activities which were halted \\ because of the COVID-19 pandemic.
}

(C) 2020 Center for Sustainability Research and Consultancy Pakistan under a Creative Commons Attribution-NonCommercial-ShareAlike 4.0

Corresponding author's email address: ayeshasiddiqua05@ gmail.com

Recommended citation: Siddiqua, A., Shabir, G., Ashraf, A. \& Khaliq, A. (2020). Media Framing of Pandemics: A Case Study of the Coverage of COVID-19 in Elite Newspapers of Pakistan. Journal of Business and Social Review in Emerging Economies, 6(4), 1267-1275

\section{Introduction}

The threats of Global pandemics are considered as the most serious threats to the contemporary human societies (Davis, 2005; Elbe, 2010; Fidler, 2004). The actual idea of pandemic is quite threating for the 
whole world as the challenges related to controlling and mapping the disease are not limited to the immediate location of the outbreak. The post-world war optimism of the developed world sent the threat of pandemics to the history books because of the evolution of vaccines, anti-viral medications and antibiotics (Abraham, 2007; Dry and Leach, 2010). But the spread of fatal infections which became resistant to prevalent antibiotic treatments (Abraham, 2007; Dry and Leach, 2010) made even the western developed world realize about the intensity of its vulnerability. In the cases of Ebola, SARS and H1N1 flu the consequences of epidemics were manifested in a multifold manner because of the enhanced levels of global connectivity (Pieri, 2019).

The Coronavirus disease (COVID-19) illustrated that how a pandemic which started in China could travel so fast to the rest of the world while causing widespread havoc and panic across the globe. Patients infected with COVID-19 were prone to respiratory illness ranging from mild to moderate. As per the World Health Organization's directives "the best way to prevent and slow down transmission is to be well informed about the COVID-19 virus, the disease it causes and how it spreads" (World Health Organization, 2020). The emphasis on the acquisition of information regarding the virus made it possible not only for the media to give the issue tremendous amount of coverage but also allowed the audience to be more attentive and receptive towards all sorts of available information. COVID -19 was speculated to emerge from a wild life market of China situated at the city of Wuhan in the year 2019. Although a report by EU has accused China of manipulating the information regarding the crisis but China rejected all such accusations along with rejecting the call for any independent investigation regarding the origin of the virus (Coronavirus: China rejects call for probe into origins of disease, 2020).

The role of mass media in the time of pandemics can be viewed extremely critical not only with respect to creating awareness about the disease but also in terms of enhancing the chances of better survival of the contemporary human societies. This paper attempted to comprehend the development of media frames in the coverage of COVID-19 along with analyzing the patterns through which the impact and risks related to COVID-19 were presented in the e papers of the mainstream English press of Pakistan. The significance of the study lies in its focus to comprehend the evolution and development of frames which were dominantly used by the Pakistani press to tackle the humanitarian crisis which emerged because of the COVID -19 pandemic.

\section{Media Coverage of Pandemics}

In the unpredictable times of pandemic spread the role of media gains greater attraction as it sets the agenda for public debate and at the same time helps people in knowing about the risks related to the pandemic. The outbreak of corona pandemic coincided with a time in evolution when the sources of information dissemination have become most sophisticated and the acquisition of information itself has acquired the position of one of the most valued entities.

The significant role of media in case of pandemics cannot be undermined as the mechanisms of scrutiny by the World Health Organization (WHO) are themself dependent on the information provided by different sources of media, along with official communication channels (Dry, 2010). Studies on the media coverage of pandemics have also incorporated innovative ways of operationalizing data gathered from posts, tweets, blogs and social media. The early detection of health crisis had also incorporated the technique of sentiment analysis (Schulz et al., 2013). The dependence on media was also significant for its potential to guide in the case of absence or failure of formal support systems and also to communicate health and emergency related messages to different segments of the society. A research conducted by Time Magazine showed that compared to the English language print coverage of Ebola epidemic in 2018 the articles published on COVID-19 were considerably greater in number (Ducharme, 2020). Luther \& Zhou (2005) examined the media framing of SARS virus by the Chinese and U.S. print media and they concluded that the dominant frames used for covering the SARS virus included responsibility, human interest, leadership, conflict and economic consequences.

Although the significance of social media analysis holds a vital position but the coverage of national 
newspapers still played a significant role in shaping the policy and public discussions on matters pertaining to health emergencies (Dry and Leach, 2010). The connection between health communication and journalism is often examined through the lens of framing. Scheufele and Tewksbury (2007) asserted that framing can be understood as an assumption in terms of how news is portrayed in the media is bound to have an influence on how it is perceived by the audience. The issues that received more information were also considered more important by the members of audience as the media not only tells us what to think but also what to think about (Entman, 1993). Entman (2007) further asserted that classification of media frames can be divided into different categories with respect to the functions they perform. These functions can be classified with respect to defining the problem, mapping out causal interpretations, and providing recommendations. The concept of framing has been widely employed by researchers across a wide range of themes. Frames can be interpreted as a sequence of cognitive schemes through which we perceive, communicate, organize and prioritize the information regarding certain issues while keeping the context in view (Pieri, 2009). It is through the process of framing that media attains the ability to attract attention towards a particular issue (Entman, 2007). In terms of health crisis especially in the scenario of COVID-19 pandemic media framing helped in imparting significance to the information regarding pandemic (Liu \& Kim, 2011). Prospect theory by Kahneman \& Tversky (1979) also suggested that the messages containing gain-frames like accentuating the benefits of hand washing were highly likely to be more persuasive than the messages containing loss-frames like accentuating the risks of virus as a result of not washing hands. The study at hand is exploratory in nature as not much synchronized literature was available regarding the media framing of pandemics in general and COVID19 framing in particular.

\section{Methodology}

The study aimed at exploring the dominant frames used in the coverage of COVID-19 by the Pakistani English e papers. In the wake of COVID-19 pandemic the sales of hard copies of newspapers decreased as they were considered a possible source of infection. Resultantly the online readership of the newspapers grew. Newspaper media coverage of pandemics in both print and online mediums has continued to influence the framing of policy and public debates (Wald, 2008; Stephenson and Jamieson, 2009; Dry and Leach, 2010). Entman (1993) while explaining the process of framing asserted that "to frame is to select some aspects of a perceived reality and make them more salient in a communicating text, in such a way as to promote a particular problem definition, causal interpretation, moral evaluation, and/or treatment recommendation for the item described" (p.52).

The coverage was analyzed through qualitative inductive content analysis of the COVID-19 related news stories published in the e papers of Dawn and Express Tribune. The stories published from the time period of 01 April, 2020 to $30^{\text {th }}$ April 2020 were retrieved from the Lexis Nexus database. The time period was significant because of the increase in the number of COVID-19 patients in Pakistan. Total 45 stories were retrieved. Among the selected stories 20 stories comprised of Daily Dawn and 15 stories comprised of the Daily Express Tribune. The unit of analysis was every individual story. The selected stories were analyzed through the process of careful open coding as a result of which three key themes emerged with respect to the coverage of COVID-19 pandemic which included Scientific Development related to Pandemic; Scale of Pandemic; Social \& Economic Impact of the Pandemic.

\section{Findings}

The recurrent themes which emerged as a result of open coding are discussed in detail along with the dominantly employed frame categories.

\subsection{Scientific Development Related to Pandemic}

Stories falling under the theme of scientific development incorporated frame categories related to definition of the pandemic; medical updates; health related precautions; development of vaccines; new findings regarding the causes and symptoms of COVID-19. 
In a story published in Dawn regarding the development of Corona Virus vaccine the World Health Organization said that it will supervise the research about COVID- 19 treatment in Pakistan especially to comprehend the effectiveness of malaria drugs in the corona treatment. The story also dealt with the mutation aspect of the virus as it mutates while travelling from one population to another (WHO oversees research to develop corona treatment in Pakistan, 2020).

In a similar story published in the Express Tribune, the successful genome sequencing carried out by University of Karachi was reported. The story also reported that the sequencing was carried out to comprehend the genetics of Corona virus and the whole process was done under the supervision of both young and senior Pakistani doctors (Pakistan carries out whole genome sequencing to help combat COVID-19, 2020).

In the time of a pandemic with such common symptoms an obvious challenge was to get oneself tested. In a related story published in Dawn a step-by-step guide was shared with the readers for how to get their COVID-19 related symptoms checked in Pakistan. The story incorporated the versions of health professionals to explain the process through which a person can be tested for COVID-19. In the first step in case of any manifested symptoms the patient was advised to visit any public or private hospital which was designated by the government. At the designated hospital the doctor will check the patient in order to determine broadly if he or she may be suffering from coronavirus. In case the doctor rules out the option of corona virus the patient will be asked to go back. In case the doctor concludes that the patient has corona symptoms a swab of his saliva will be taken and sent for testing. Further the story also stated that at government facilities the test would be done free of cost. Along with the government designated facilities it was also mentioned that some of the private labs were also conducting tests against a certain fee (Here's how you can get checked for coronavirus in Pakistan, 2020).

In another story published in Dawn the usefulness and legitimacy of world Health Organization (WHO) was questioned with reference to the pandemic spread and the steps taken to contain its harmful effects ("WHO and COVID-19", 2020). In a story published in The Express tribune the issue of disposal of hospital waste was highlighted (Ahmed, 2020). The story stated that the contaminated medical waste of hospitals in Karachi posed a serious threat in terms of increasing the infection rate. The complaints of the hospital staff were also made part of the story in which they asserted that they were not provided with any special instructions with respect to dumping the waste of the infected patients. The story also gave background information on how the disposal of medical waste had remained an unresolved issue in Pakistan even in the pre corona scenario. The public hospitals' representatives, on the contrary, assured that hospital waste was properly disposed of. Infection Control Society of Pakistan also endorsed the point of view of the hospital staff by asserting that the possibility of the spread of COVID-19 virus from the highly contaminated waste was very high (Ahmed, 2020).

Thus the news stories falling under this theme were mostly meant to educate the readers so that they can have a very clear idea of the problem that they are dealing with. The writing style of these stories was mostly kept simplistic. The difficult jargon related to medicine was mostly avoided and where the use of jargon was unavoidable the jargon was properly explained.

\subsection{Scale of Pandemic}

Stories falling under the theme of "Scale of Pandemic" incorporated frame categories related to mapping the evolving trends in domestic infection cases; facts and figures related to infected, recovered patients and critically ill patients; number of pandemic related deaths; mode of transmission of COVID-19.

In a story filed from Karachi the increasing number of corona cases in some parts of Karachi was highlighted. The areas of Karachi which reported the highest number of corona cases were emphasized including Gulshan-i-Iqbal, North Nazimabad and Saddar. The story also included the facts that patients with underlying health conditions like diabetes and hypertension were more prone to succumb to the 
disease. The district wise breakdown of the corona patients in Sindh was also made part of the story. "The data showed that while most cases were reported among the age-group 20-29 years (21pc) followed by age-group 30-39 years (19pc), people at the age of 70 and above are the most severely affected age group followed by 60-69 years.... whereas the gender wise analysis showed that 70pc patients were men whereas 30pc were women" (Illyas, 2020). The stories like these which were rich in data helped in prioritizing the areas and parts of population which need to be focused in order to effectively deal with the COVID-19 breakout in terms of policy formulation.

In another story the "highest single day tally" related to COVID- 19 cases till April 19, 2020 were reported by The Express Tribune. The story started with the background information regarding the corona virus and then moved on to the current situation which stated that 1,137 patients were reported till date (April 19: Sindh record highest single-day tally of Covid-19 cases, 2020). In a similar story published by Dawn a detailed graphical story was reported when the number of deaths crossed 100 in Pakistan and how it took Pakistan among the world's $40^{\text {th }}$ country to be severely effected by COVID-19 (Junaidi, 2020). The story further reported deaths and scale of pandemic province wise in Pakistan.

In an opinion story published in The Express Tribune the writer warned about the ever increasing scale of COVID-19 pandemic and how Pakistan is extremely vulnerable with its inadequate hygiene and health systems (Ahmar, 2020). The writer of the story also drew a comparison between the government's claims of containing the virus and the competing ground realities. The challenges of social distancing in densely populated localities along with ever increasing income pressures faced by the middle and lower middle classes were also highlighted in the story. The "inability" of the people sitting in power to enforce right measures was linked to the increasing levels of frustration among the people. The writer further elaborated on the social and psychological implications of the pandemic faced by different segments of the Pakistani society (Ahmar, 2020).

Thus the stories falling under this theme mostly comprised of the unfolding information regarding the pandemic. Most of the stories were developing in nature as the pandemic itself was unfolding itself at a very fast pace. The information was mostly compiled in manner which was meant to warn both the readers and the policy makers about the tremendously growing scale of the pandemic.

\subsection{Social \& Economic Impact of the Pandemic}

The stories falling under the theme of social and economic impact comprised of the frame categories related to recommendations for reviving the economy crisis; social distancing; lockdown; charity; apathy; foreign help; economic impact of the pandemic at domestic and international level; economic relief to individuals and small and large scale enterprises by the government.

In a story published in Dawn the Prime Minister of Pakistan urged the Pakistani nation to donate for the Coronavirus Relief Fund as the funds will be utilized to provide relief to the segments of the society who are hit hardest because of the coronavirus lockdown measures. Along with asking for donations the Pakistani Prime Minister also urged the youth to step forward in these difficult times and provide essentials and food items to the struggling strata and also play their part in minimizing the effects of corona virus. For this purpose the registration of youngsters in the PM's Corona Tiger Force was also encouraged (Covid-19 relief fund: PM urges people to donate so government can take care of those in need, 2020).

In a story published in The Express Tribune the alliance between China and Pakistan was highlighted as China pledged more help for Pakistan in order to fight the corona pandemic. The story was filed in the backdrop of the meeting between Pakistani Foreign Minister Shah Mahmood Qureshi and the Chinese Ambassador to Pakistan Yao Jing. As the Pakistani FM congratulated the Chinese Ambassador over "successfully dealing with the pandemic" the Chinese Ambassador asserted that China "would 
continue its support for its iron brother" (China pledges more help to Pakistan in fight against corona pandemic, 2020).

A story published in Dawn focused on the different strategies that can be adopted by the freelancers to survive their businesses during the pandemic (Saleem, 2020). As a result of the massive layoffs in the job market the sources of income generation for freelancers were also equally dried up because of the loss of the clientele. The story educated the freelancers regarding certain steps that can be taken to minimize the effects of economic downturn for the freelancers. The recommendations included reviewing the business tools and expenses, exploring alternative options of financing, harnessing business network, transferring the work to online platforms, optimizing work space and routine, encouraging flexibility, focusing on innovation and investing in the development of skills (Saleem, 2020).

The impact of coronavirus on the economy was discussed at length in another story published by The Express Tribune (Rehman, 2020). The story also incorporated the information regarding conspiracy theories through which the crisis is seen not as targeted towards public health rather seen as a "politically motivated agenda to transform the global economy". The adverse effects of lockdown on Pakistani economy could result in the squeezed livelihood opportunities for small and medium businesses and daily wage earners in particular. The story also correlated the effects of closure of businesses, industries, transport and airports to the overall condition of the economy. The story reiterated the fact that although Pakistan's economy has withstood many challenges in the past but the current situation requires more apt public policy and its implementation (Rehman, 2020).

The details regarding smart lockdowns and its effectiveness in dealing with Covid-19 spread was discussed at length in a story published in Dawn ("Smart lockdowns lead to effective handling of Covid19 in Pakistan", 2020). The decline in the number of COVID related deaths was attributed to the smart lockdown strategy in Pakistan. The acknowledgment in this regard was made by the Medical Microbiology and Infectious Diseases Society of Pakistan. The story further stated that the isolation centers which were established in Karachi and Lahore were not used to their full capacity owing to smart lockdown strategy. In a similar story published in The Express Tribune the government's strategy to "ease lockdown" was related to the reporting of lesser number of cases in comparison to the projected number of cases ("April 29: Govt prepares to ease lockdown, considers 15, 525 Covid-a9 cases as below projections", 2020). The story stated that Pakistan despite being close to China remained relatively free from virus for a much longer period of time but the number of cases spiked as pilgrims who returned from Iran tested positive for COVID-19.

The stories falling under this theme mostly comprised of the direct human interest stories as they dealt with areas which directly affected the everyday life of individuals in terms of their economic and social preferences. The stories also provided recommendations for the economic and social revival of the Pakistani society in particular and the world at large.

The recurrent themes in the selected content and the dominant frame categories employed for framing COVID-19 pandemic by the Pakistani media are summarized in the following figure:

\begin{tabular}{l|l}
\hline Themes & Dominant Frame Categories \\
\hline Scientific Development related to pandemic & $\begin{array}{l}\text { Defining the pandemic; medical updates; health related } \\
\text { precautions; development of vaccines; new findings } \\
\text { regarding the causes and symptoms of pandemic }\end{array}$ \\
\hline Scale of Pandemic & $\begin{array}{l}\text { Trends of domestic infection cases; mode of pandemic } \\
\text { transmission; facts and figures related to infected; } \\
\text { statistics related to patients (recovered and critically ill); }\end{array}$ \\
\hline
\end{tabular}




\begin{tabular}{l|l}
\hline Social \& Economic Impact of the Pandemic & number of pandemic related deaths; \\
& $\begin{array}{l}\text { Recommendations for reviving the economy crisis; } \\
\text { social distancing; lockdown; charity; apathy; foreign } \\
\text { help; economic impact of the pandemic at domestic and } \\
\text { international level; economic relief }\end{array}$ \\
\hline
\end{tabular}

\section{Discussion and Conclusion}

Effective and timely communication strategies by the health and government departments for public awareness have mostly played a pivotal role in handling pandemic situations. The media framing of these strategies helps the public in adopting required precautions to control the outbreak along with limiting the mortality and morbidity rates. As Barry (2009) rightly pointed that " in the next influenza pandemic, be it now or in the future, be the virus mild or virulent, the single most important weapon against the disease will be a vaccine. The second most important will be communication" (p. 1039). The connection between health communication and journalism is often examined through the lens of framing. Scheufele and Tewksbury (2007) asserted that framing can be understood as an assumption that how news is portrayed in the news is bound to have an influence on how it is perceived by the audience. Entman (1993) while explaining the process of framing said that "to frame is to select some aspects of a perceived reality and make them more salient in a communicating text, in such a way as to promote a particular problem definition, causal interpretation, moral evaluation, and/or treatment recommendation for the item described" (p.52). Thus framing is one of the most frequently applied theories in terms of comprehending the coverage of disasters (Durham, 1998; Haider-Markal, Delehanty, \& Beverlin, 2007). Media framing also traces its origin to cognitive psychology as framing heavily relies on the ideas, concepts and feelings which are stored in human memory in the form of a node and connected to each other through semantic tracks (Price \& Tewksbury, 1997). Resultantly the way health issues are framed in the media has impact on the audiences' comprehension of those particular health issues.

Entman (1993) asserted that the issues which received more information were also considered more important by the members of audience as the media not only tells us what to think but also what to think about The study analyzed the dominant frames used in the coverage of COVID 19 pandemic by the e versions of the mainstream English press of Pakistan. Three broad themes emerged as a result of the inductive content analysis which included Scientific Development related to pandemic; Scale of Pandemic; Social and Economic impact of Pandemic.

Stories falling under the theme of scientific development incorporated frames related to defining the pandemic; medical information; health related precautions; development of vaccines; new findings regarding the causes and symptoms of COVID-19. The news stories falling under this theme were mostly meant to educate the readers as factually and as succinctly as possible. Stories falling under the theme of "Scale of Pandemic" incorporated frames related to mapping the evolving trends in domestic infection cases; facts and figures related to infected, recovered and critically ill patients; number of pandemic related deaths; mode of transmission of COVID-19. The stories falling under this theme mostly comprised of the unfolding information regarding the pandemic. The information was mostly compiled in manner which was meant to warn both the readers and the policy makers about the tremendously growing scale of the pandemic. The stories falling under the theme of Social and Economic impact of pandemic comprised of the recommendations related to revival of the economic and social activities; social distancing; lockdown; charity; apathy; foreign help; economic impact of the pandemic at domestic and international levels; economic relief to individuals and small and large scale enterprises. Thus the study supported the view that it is through the process of framing that media attains the ability to attract attention towards a particular issue (Entman, 2007). In terms of health crisis especially in the scenario of COVID-19 pandemic media framing helped in imparting significance to the information regarding pandemic (Liu \& Kim, 2011). 
Although this research was mostly exploratory in nature because of the unfolding patterns of the pandemic coverage during the selected time period but it helped the researchers in locating the following areas for future inquiry:

- Role of Journalists and reporters in health emergencies as front line workers

- Dependence of public policy makers on media framing in matters related to public health

- Media coverage of pandemics and its effects on stimulating strokes of panic and fear among the audience

\section{References}

Abraham T (2007) Twenty-First Century Plague: The Story of SARS. Baltimore, MD: John Hopkins University Press.

Ahmar, M. (2020, April 17). As the pandemic crisis deepens. The Express Tribune. Retrieved from https://tribune.com.pk/story/2199641/6-pandemic-crisis-deepens/

Ahmed, T. (2020, April 16). No SOPs for disposal of Covid-19 waste in Sindh. The Express

Tribune. Retrieved from https://tribune.com.pk/story/2198989/no-sops-disposal-covid 19-waste-sindh

April 19: Sindh record highest single-day tally of Covid-19 cases. (2020, April 19). The Express Tribune. Retrieved from https://tribune.com.pk/story/2201667/1-live-new-cases-reported punjab-islamabad-nationwide-tally-hits-7993/

Barry, J. M. (2009). Pandemics: avoiding the mistakes of 1918. Nature, 459(7245), 324-325

China pledges more help to Pakistan in fight against corona pandemic. (2020, April 09). The

Express Tribune. Retrieved from https://tribune.com.pk/story/2194377/1-china-pledges help-pakistan-corona-fight/

Coronavirus: China rejects call for probe into origins of disease. (2020, April 24). BBC News.Retrieved from https://www.bbc.com/news/world-asia-china-52420536

Covid-19 relief fund: PM urges people to donate so govt can take care of those in need. (2020, April

01). Dawn. Retrieved from https://www.dawn.com/news/1545558

Davis M (2005) .The Monster at Our Door: The Global Threat of Avian Flu. New York: The New Press.

Durham, F. D. 1998. News frames as social narratives: TWA Flight 800. Journal of Communication, 48(4): 100-117.

Dry S and Leach M (eds) (2010) Epidemics: Science, Governance and Social Justice. London: Earthscan.

Ducharme, J. (Feb 07, 2020). News Coverage of Coronavirus in 2020 is Very Different Than it Was For Ebola in 2018. Time. Retrieved from https://time.com/5779872/coronavirus ebolanews coverage/

Elbe ,S. (2010) Security and Global Health. Cambridge: Polity Press.

Entman, R . (1993) . Framing: Toward clarification of a fractured paradigm. Journal of Communication 43(4): 51-58.

Entman R (2007) Framing bias: Media in the distribution of power. Journal of Communication 57: $163-173$.

Fidler D (2004) SARS, Governance and the Globalization of Disease. New York: Palgrave Macmillan.

Govt prepares to ease lockdown, considers 15,525 Covid-19 cases as below projections. Dawn. hits-14885

Retrieved from https://tribune.com.pk/story/2209564/new-cases-reported-punjab national-tally- 
Here's how you can get checked for coronavirus in Pakistan. (2020, April 01). Dawn. Retrieved from https://www.dawn.com/news/1538338

Haider-Markel, D. P., Delehanty, W. and Beverlin, M. 2007. Media framing and racial attitudes in the aftermath of Katrina. Policy Studies Journal, 35: 587-605.

Illyas, F. (2020, April, 11). Gulshan, Saddar report highest number of Covid-19 cases in Karachi. Dawn.

Retrieved from https://www.dawn.com/news/1548197/gulshan-saddar-report highest number-of-covid-19-cases-in-karachi

Junaidi, I. (2020, April 15). Pakistan becomes $40^{\text {th }}$ country with 1 oo COVID-19 deaths. Dawn. Retrieved from https://www.dawn.com/news/1549287

Kahneman, D. and Tversky, A. 1979. Prospect theory: An analysis of decision under risk. Econometrica, 47: 263-291.

Liu, B. F., \& Kim, S. (2011). How organizations framed the 2009 H1N1 pandemic via social and traditional media: Implications for US health communicators. Public Relations Review, 37(3), 233-244.

Luther, C. and Zhou, X. 2005. Within the boundaries of politics: News framing of SARS in China and the United States. Journalism and Mass Communication Quarterly, 82: 857872.

Pakistan carries out whole genome sequencing to help combat COVID-19. (2020, April, 01). The Express Tribune. Retrieved from https://tribune.com.pk/story/2188185/1-pakistan carries-whole-genome sequencing-help-combat-covid-19/

Pieri, E. (2019). Media Framing and the Threat of Global Pandemics: The Ebola Crisis in UK Media and Policy Response. Sociological Research Online, 24(1), 73-92.

Price, V., Tewksbury, D. and Powers, E. 1997. Switching trains of thought: The impact of news frames on readers' cognitive responses. Communication Research, 24: 481-506

Rehman, F. Covid-19 and impact on economy. The Express Tribune. Retrieved from https://tribune.com.pk/story/2202021/2-covid-19-impact-economy/

Schulz A, Thanh T, Paulheim H, et al. (2013) A fine-grained sentiment analysis approach for detecting crisis related microposts. In: Proceedings of the10th international ISCRAM confer- ence 2013 (ed T Comes, F Fiedrich and S Fortier, et al.), Baden.

Scheufele, D. A., \& Tewksbury, D. (2007). Framing, agenda setting, and priming: The evolution of three media effects models. Journal of communication, 57(1), 9-20.

Saleem, H. (2020, April 02). 10 Strategies to help your freelance business survive the COVID-19

Pandemic. Dawn. Retrieved from https://www.dawn.com/news/1544130

Smart lockdowns lead to effective handling of Covid-19 in Pakistan. (April 11, 2020). Retrieved from https://www.dawn.com/news/1573697

Stephenson N and Jamieson M (2009) Securitising health: Australian newspaper coverage of pandemic influenza. Sociology of Health and Illness 4: 525-539.

WHO oversees research to develop corona treatment in Pakistan. (2020, April 16). Dawn. Retrieved fromhttps://www.dawn.com/news/1549628/who-oversees-research-to develop-coronatreatment-in-pakistan

$\underline{W H O}$ and COVID -19 . (April 19, 2020). Dawn. Retrieved from https://www.dawn.com/news/1550454

World Health Organization. (2020, April 25). Coronavirus. Retrieved fromhttps://www.who.int/healthtopics/coronavirus\#tab=tab_1 